\title{
PLASMA PHOSPHATASE AND PHOSPHORUS DURING THE HEALING OF FRACTURES IN CHILDREN
}

BY

\author{
OLIVE D. PEDEN, B.Sc.
}

(From the Surgical Department and Biochemical Laboratory, Royal Hospital for Sick Children, Glasgow.)

Robison and his co-workers ${ }^{7}$ have shown that phosphatase is closely associated with the process of calcium deposition in bone. Wilkins and Regen ${ }^{9}$ and Botterel and King ${ }^{2}$ found that in animals there was an increase in the phosphatase activity of bone at the site of fracture: this began about four days after the injury and reached its maximum about seventeen days later. It is to be expected therefore that the plasma phosphatase which is derived at least in part from bone, would show changes during the process of repair following an injury to bone. Kay ${ }^{5}$ and Bodansky and $\mathrm{Jaffe}^{1}$ found that there was an increase in plasma phosphatase at this period. Hunsberger and Ferguson ${ }^{3}$ in eighteen patients observed an increase occurring some time after the fracture and a slow reduction as healing took place. In a recent paper Mitchell ${ }^{6}$ gave the results of serial determinations in seventy-five adult patients with fractures. He found that in many cases there occurred a slight increase in plasma phosphatase which was not proportional either to the amount or rate of healing.

The present investigation was undertaken in order to determine if in children in whom the bone-forming mechanism is much more active than in adults, a greater rise in the plasma phosphatase after an injury to bone could be demonstrated. The ages of the patients ranged from five to twelve years. Plasma phosphatase, serum inorganic phosphorus and calcium were determined in sixty-two patients. In thirty-seven cases this was done within three days of the fracture, in twenty, six to eight days later, in twelve on the thirteenth to the fifteenth day, in four on the twentysecond day and in ten on the fourth week or later. Unfortunately it was not considered advisable to repeat a blood analysis in more than a few patients.

The method adopted for the estimation of phosphatase was that of Jenner and $\mathrm{Kay}^{4}$. By this method it has been found ${ }^{10}$ that in apparently healthy children of three to thirteen years the plasma phosphatase varies between $3 \cdot 0$ and 10.0 units with an average value of 6.92 . 


\section{Results}

Phosphatase.-Taking the series as a whole, it was found that immediately after the fracture there was an increase in plasma phosphatase which fell to a minimum value at two or three weeks, after which time there occurred a secondary rise. This is best illustrated in patients with fracture of the femur. In this group the minimum value was obtained at

TABLE 1.

Average values of plasma phosphatase (units) and serum phosphorus (Mgi. per cent.).

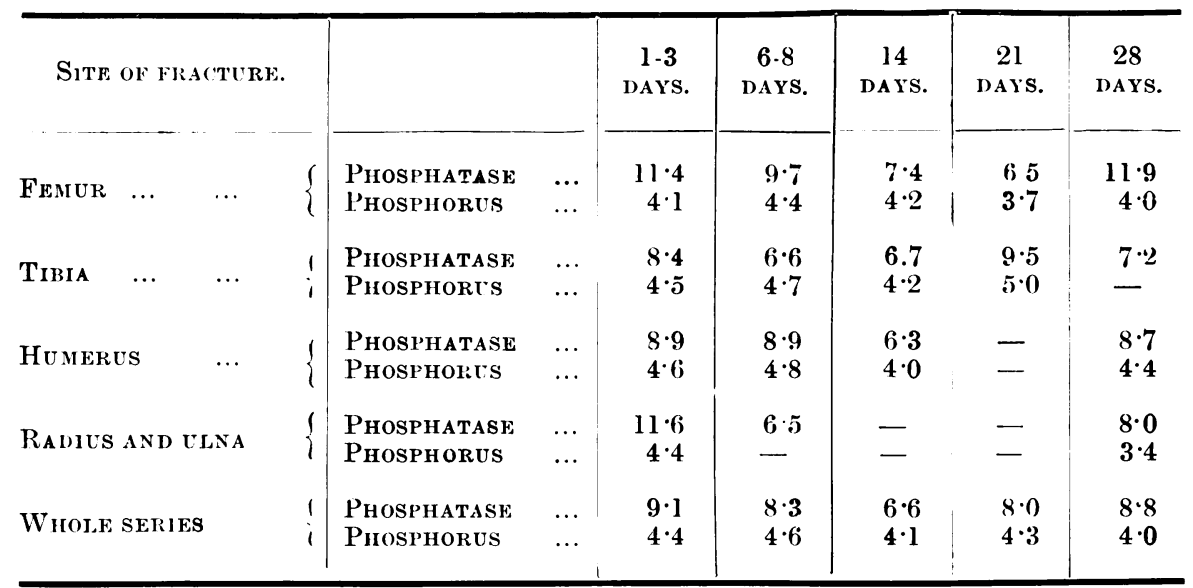

three weeks and the secondary rise occurring after the third week was much more marked than in any of the other groups. Repeated determinations of plasma phosphatase were made in eleven patients. The results shown in table 2 indicate the tendency for the phosphatase value to be high shortly after the fracture, and thereafter to fall. Of the eleven cases in this group only two showed an increase at the end of one week; in all the others there was a definite reduction.

Two patients are not included in table 2 as estimations of phosphatase were not undertaken until some weeks after the fracture had been sustained. In one of these with a compound fracture of the left tibia, union was extremely slow and the plasma phosphatase remained low from the sixth to the ninth week. Mitchell ${ }^{6}$ in cases with delayed union observed a sharp rise in phosphatase at the end of the first week but otherwise nothing to distinguish them from those in which union took place at the usual time. In the other patient with a fracture of the left radius that had united in a bad position the bone was broken and reset. This led to an immediate reduction of phosphatase from 8.0 to $5 \cdot 7$ units. 
Calcium.-No significant changes were observed in the values for serum calcium.

Phosphorus.-Tisdall and Harris ${ }^{8}$ found that serum phosphorus increased in value during the period of fracture healing and suggested that the absence of such an increase frequently heralded long delay in union. Mitchell $^{6}$, however, could not confirm these findings. In the present series, the figures obtained for serum phosphorus indicate that an increase takes

TABLE 2.

Repeated estimations in individual patients.

(Phosphatase-units : Phosphorus-mgm. per cent.)

\begin{tabular}{|c|c|c|c|c|c|c|c|}
\hline $\begin{array}{l}\text { Site OF } \\
\text { FRACTURE. }\end{array}$ & Name. & & $\begin{array}{c}1 \cdot 3 \\
\text { DAYS. }\end{array}$ & $\begin{array}{c}6 \cdot 8 \\
\text { DAYS. }\end{array}$ & $\begin{array}{c}14 \\
\text { DAYS. }\end{array}$ & $\begin{array}{c}21 \\
\text { DAYS. }\end{array}$ & $\begin{array}{c}28 \\
\text { DAYS }\end{array}$ \\
\hline \multirow[t]{5}{*}{ FEMOR } & J. McG. & $\begin{array}{l}\text { Phosphatase } \\
\text { Phosphorus }\end{array}$ & $\begin{array}{r}11 \cdot 1 \\
4 \cdot 6\end{array}$ & $\begin{array}{l}8 \cdot 4 \\
5 \cdot 4\end{array}$ & - & - & $\begin{array}{r}13.3 \\
4 \cdot 0\end{array}$ \\
\hline & J. L. & $\begin{array}{l}\text { Phosphatase } \\
\text { Phosphorus }\end{array}$ & $\begin{array}{r}12 \cdot 0 \\
3 \cdot 8\end{array}$ & 二 & $\begin{array}{l}9: 1 \\
4 \cdot 2\end{array}$ & - & - \\
\hline & J. S. & $\begin{array}{l}\text { Phosphatase } \\
\text { Phosphorus }\end{array}$ & $\begin{array}{r}10 \cdot 7 \\
3 \cdot 5\end{array}$ & - & - & $\begin{array}{l}7 \cdot 8 \\
3 \cdot 7\end{array}$ & - \\
\hline & W. O'I & $\begin{array}{l}\text { Phosphatase } \\
\text { Phosphorus }\end{array}$ & $\begin{array}{r}11 \cdot 9 \\
3 \cdot 8\end{array}$ & $\begin{array}{l}6 \cdot 7 \\
3 \cdot 9\end{array}$ & - & - & - \\
\hline & W. K. & $\begin{array}{l}\text { Phosphatase } \\
\text { Phosphorus }\end{array}$ & $\begin{array}{l}8 \cdot 8 \\
5 \cdot 6\end{array}$ & $\begin{array}{l}5 \cdot 7 \\
5 \cdot 7\end{array}$ & - & - & $\begin{array}{c}13 \cdot 3 \\
-\end{array}$ \\
\hline \multirow[t]{4}{*}{ Tibia $\ldots$} & H. M. & $\begin{array}{l}\text { Phosphatase } \\
\text { Phosphorus }\end{array}$ & $\begin{array}{r}10 \cdot 1 \\
3 \cdot 6\end{array}$ & $\begin{array}{l}5 \cdot 3 \\
3 \cdot 9\end{array}$ & - & - & - \\
\hline & J. D. & $\begin{array}{l}\text { Рhosphatase } \\
\text { Phosphorus }\end{array}$ & $\begin{array}{l}8 \cdot 8 \\
4 \cdot 2\end{array}$ & - & - & $\begin{array}{r}10 \cdot 5 \\
4 \cdot 2\end{array}$ & - \\
\hline & M. P. & $\begin{array}{l}\text { Phosphatase } \\
\text { Phosphorus }\end{array}$ & $\begin{array}{l}6 \cdot 9 \\
4 \cdot 8\end{array}$ & $\begin{array}{l}8 \cdot 9 \\
5 \cdot 8\end{array}$ & - & - & - \\
\hline & J. F. & $\begin{array}{l}\text { Phosphatase } \\
\text { Phosphorus }\end{array}$ & $\begin{array}{l}5 \cdot 9 \\
4 \cdot 3\end{array}$ & $\begin{array}{l}3 \cdot 7 \\
5 \cdot 0\end{array}$ & $\begin{array}{l}3 \cdot 9 \\
4 \cdot 3\end{array}$ & - & - \\
\hline \multirow[t]{2}{*}{ Humerus } & M. H. & $\begin{array}{l}\text { Phosphatase } \\
\text { Phosphorts }\end{array}$ & - & $\begin{array}{l}8 \cdot 9 \\
5 \cdot 1\end{array}$ & $\begin{array}{l}5 \cdot 0 \\
4 \cdot 6\end{array}$ & - & - \\
\hline & W. D. & $\begin{array}{l}\text { Phosphatase } \\
\text { Phosphorus }\end{array}$ & $\begin{array}{l}7 \cdot 7 \\
4 \cdot 2\end{array}$ & $\begin{array}{r}10 \cdot 4 \\
6 \cdot 0\end{array}$ & - & - & - \\
\hline
\end{tabular}

place about one week after the injury. The averages at one week show a rise of $0.2 \mathrm{mgm}$. per cent. (table 1) but in individual cases (table 2) this figure is frequently exceeded. Hunsberger and Ferguson ${ }^{3}$ observed that serum phosphorus and phosphatase values moved in opposite directions during the healing of fractures. Mitchell ${ }^{6}$ could find no evidence of this inverse movement. The figures given in table 1 and 2 suggest, however, that there is some tendency for the plasma phosphorus and phosphatase to 
move in opposite directions, thus resembling what takes place during the healing of rickets.

Site of fracture.-Table 3 shows that in the present series high values for plasma phosphatase tend to occur in fractures of the femur. Of seven cases with fractured femur examined within three days of the accident, five (70 per cent.) had a plasma phosphatase above 11.0 units. With fracture of the forearm bones the incidence of high values was four in ten, of the

TABLE 3.

Showing INCIDENCE OF HIGH PHOSPHATASE VALUES OBTAINED WITHIN THREE DAYS OF FRACTURE.

Site oF

Fracture.
Total Number

of CASES.

Femur .

Tibia

HUMERUS

RADIUS ...

RADIUS

humerus three in nine and of the tibia only one in eleven. The results recorded for the present series resemble those obtained by Mitchell ${ }^{6}$ in adult patients with multiple fractures, in whom the phosphatase was found to fall during the first two weeks and rise in the third week. In his patients with single fractures the phosphatase increased during the first week. It is possible that the more rapid increase in children is due to the fact that in this period of life growth is active, with a consequent increased tendency to form phosphatase.

\section{Summary}

The plasma phosphatase and serum phosphorus and calcium were estimated in children at various intervals after a fracture injury. The plasma phosphatase appeared to increase within the first few days and thereafter to decrease. The serum phosphorus reached a maximum at the end of the first week. The serum calcium was not significantly altered. The change in plasma phosphatase was most marked in fractures of the femur.

Thanks are due to Dr. Noah Morris and Mr. Matthew White for suggesting this investigation and for their helpful criticism throughout.

\section{REFERENCES.}

1. Bodansky, A., \& Jaffe, H. L., Arch. Int. Med., Chicago, 1934, LIV, 88.

2. Botterel, E. H., \& King, E. J., Lancet, London, 1935, i, 1267.

3. Hunsberger, A., Jr., \& Ferguson, L. K., Arch. Surg., Chicago, 1932, XXIV, 1052.

4. Jenner, H. D., \& Kay, H. D., Brit. J. Exp. Path., London, 1929, X, 253.

5. Kay, H. D., J. Biol. Chem., Baltimore, 1930, LXXXIX, 249.

6. Mitchell, C. L., Ann. Surg., Philadelphia, 1936, CIV, 304.

7. Robison, R., Biochem. J., London, 1923, XVII, 286.

8. Tisdall, F. F., \& Harris, R. I., J. Amer. Med. Assoc., Chicago, 1922, LXXIX, 884.

9. Wilkins, W. E., \& Regen, E. M., Proc. Soc. Exp. Biol. and Med., Utica, 1935, XXXII, 1373.

10. Morris, N., et al., Arch. Dis. Childh., London, 1937, XII, 45. 